\title{
Understanding Lone-Actor Terrorists: The Global Context and How it can be Applied to New Zealand
}

Author: Tillett, Josinta

To cite this article: Tillett, J. (2021). Understanding Lone-Actor Terrorists: The Global Context and How it can be Applied to New Zealand. National Security Journal. Published 29 August 2021. doi:10.36878/nsj20210829.01

To link to this article: https://doi.org/10.36878/nsj20210829.01

View CrossRef data: https://search.crossref.org/?q=10.36878\%2Fnsj20210829.01 


\title{
UNDERSTANDING LONE-ACTOR TERRORISTS: THE GLOBAL CONTEXT AND HOW IT CAN BE APPLIED TO NEW ZEALAND
}

\author{
Josinta Tillett ${ }^{1}$
}

\begin{abstract}
While the Christchurch mosque attacks on 15 March 2019 were asserted to have changed New Zealand's national security context, arguably the possibility of such an attack was foreseen, and, internationally, there was evidence of increasing risk of such attacks occurring. This paper explores the current state of international lone-actor research, and looks at how this can be applied in an endeavour to prevent future attacks in New Zealand. This paper combines an overview of the international lone-actor phenomenon, with New Zealand's historical and contemporary terrorism context, and explores the extent that international research may have a bearing on current and future lone-actor terrorism risk here. It argues careful attention to identifiable indicators and protective factors, as well as local context, as essential in the contemplation of current and future attempts to pre-emptively identify and prevent potential lone-actor terrorism in New Zealand.
\end{abstract}

Keywords: Lone-Actor Terrorist, Terrorism, New Zealand, al- Qaeda, Islamic State, Right Wing Extremism, Risk Indicators, Protective Factors

\section{Introduction}

The day of the 2019 terrorist attacks in Christchurch is considered by some, both within and outside of New Zealand's Government, to be the day New Zealand's national security context changed. While this may be so, it can also be argued that such an attack, by a lone-actor terrorist, was already considered possible, if not likely, in New Zealand. Indeed, researchers and world leaders had already highlighted the growth and higherrisk of lone-actor terrorism to the $\mathrm{West}^{1}$, and it had been cited as the most significant

1 Josinta Tillett holds a Master of International Security (intelligence) from the Centre for Defence and Security Studies, Massey University. This article is based on her research dissertation. Josinta is very grateful for the guidance, mentorship, dry humour and wit of her research supervisor, Dr John Battersby. Any correspondence in relation to this article, please contact the Managing Editor, NSJ at CDSS@Massey.ac.nz. 
terrorism risk to New Zealand ${ }^{2}$. This paper seeks to answer the question: what is the current state of international lone-actor research, and how can this help New Zealand in its endeavour to prevent future attacks? This paper will overview the development of the lone-actor phenomenon internationally, briefly outline New Zealand's historical and contemporary terrorism context as well as explore the extent of international research and the bearing it may have on New Zealand's current and future lone-actor terrorism risk. It argues careful attention to identifiable indicators and protective factors, as well as local context, as essential in the contemplation of current and future attempts to preemptively identify and prevent potential lone-actor terrorism in New Zealand.

In part, the high risk of lone-actor terrorism is due to it being difficult to prevent. Difficulties arise from the solitary nature of related attack planning, hindering identification of attackers prior to terrorism events. ${ }^{3}$ Identification is difficult because lone-actors mostly work alone, are less likely to communicate with others, and planning is less obvious to security agencies. ${ }^{4}$ In addition, security agencies are unable to apply a lone-actor typology that would assist with identification, as academic research has not been able to prescribe one $e^{5}$. Developing a typology is difficult because of behavioural and characteristic variations of lone-actors, inaccurate information provided by friends and family on successful attackers, and inaccurate reporting by media and authorities. ${ }^{6}$ In New Zealand, the absence of historical attacks, as well as a lack of attention paid to the domestic terrorism context by successive governments, also complicates this.?

Despite the reported high-risk of lone-actor terrorism and difficulties in preventing it, New Zealand security agencies need to ensure as much as possible they are enabled to counter this risk. These agencies, particularly Police, the Security Intelligence Service and Customs, must not only respond to such attacks, but must also seek to detect potential lone-actors before possible attacks occur. These agencies currently identify, triage, and prioritise possible lone-actors. Early detection is important to prevent plans from forming and to identify rehabilitation options for potential lone-actors. However, in the general absence of a specific lone-actor profile, New Zealand agencies would benefit from an evidence-based approach to undertake these prevention tasks, particularly to support the heightened security requirements following the Christchurch attacks. ${ }^{8}$

This paper seeks to fill this gap, by providing New Zealand security agencies with insight to current international research on lone-actor terrorists, particularly their characteristics, and suggests how this research might be applied to New Zealand. This has been achieved by considering the relevant international studies on lone-actor terrorism, analysing them for thematic consistencies and differences, and drawing out the main established identifying factors attributed to lone-actor terrorists. These characteristics are then compared to known case studies of New Zealand lone-actors, which in turn are assessed against a random control sample of routine criminal offenders using anonymised data. This was done to test the efficacy of an indicator-based approach to assessing the risks of potential lone-actor suspects. This paper identifies a number of 
characteristics which are common among lone-actor terrorists, with further data that relates more specifically to New Zealand circumstances. This paper reveals the possibility of developing an assessment criteria relevant to a New Zealand context.

Two issues need further explanation before proceeding. Firstly, there is no universally accepted definition of terrorism itself, and when it comes to specific types of terrorism definitions also vary. The definition of 'lone-actor terrorism' used in this research was developed at a 2015 Countering Lone-Actor Terrorism workshop in The Hague:

The threat or use of violence by a single perpetrator (or small cell), not acting out of purely personal-material reasons, with the aim of influencing a wider audience, and who acts without any direct support in the planning, preparation and execution of the attack, and whose decision to act is not directed by any group or other individuals (although possibly inspired by others). ${ }^{9}$

This definition aligns with those used by other researchers in the field, including Ramon Spaaj (2012) and Gabriel Weimann (2012), discussed below. The term 'lone-actor' is used here instead of 'lone-wolf' to avoid misconceptions that the latter term raises, including perceived levels of cunning and lethality. ${ }^{10}$ Secondly, New Zealand has historically lacked specific terrorism-related legislation. Its first enactment in 1987 - the International Terrorism (Emergency Powers) Act - dealt only with specific powers in an 'international terrorist event' and has never been evoked. It was not until the Terrorism Suppression Act (TSA) 2002 that a 'terrorist act' became an offence, and even then in 2007 the complexity of the Act's wording rendered it practically unusable unless applied after the fact. Until Brenton Tarrant pleaded guilty in 2020 for the Christchurch mosque attacks, legally speaking New Zealand had never had a terrorist. Academic attention on terrorism in New Zealand has also been lacking, until John Battersby more recently authored a number of articles focused on the issue. Battersby argues that despite the legal deficiency, New Zealand has experienced terrorism, and certain acts committed here - if committed in most other countries - would have been regarded as terrorism. ${ }^{11}$ Therefore, the New Zealand cases discussed in this article are those that, in the assessment of the author, meet the definition outlined above and, if not 'legally' regarded as terrorism in New Zealand, they are nevertheless relevant to a discussion about it.

\section{The Lone-actor Phenomenon}

Over the past 30 years, there has been a noticeable growth internationally in loneactor terrorism with the number of such attacks increasing every decade. ${ }^{12}$ Lone-actor terrorism is particularly prevalent in the US, with rates there being much higher than those of all other countries. ${ }^{13}$ From 1970-2010 lone-actor attacks in the US rose by 45 percent per decade (22-32 attacks per decade), ${ }^{14}$ and the number of individuals killed increased from four per decade in the 1960s, to 115 in the 2010s. ${ }^{15}$ Rates in the US 
continued to rise, with a 2020 report stating that at least 30 attacks and 20 deaths were recorded across the US and Canada every year since $2014^{16}$. Increases have also occurred elsewhere. From 1970-2010, lone-actor attacks in Europe rose by 412 percent (8-41 attacks per decade $)^{17}$, with further increases seen to at least $2018 .{ }^{18}$ Despite the significant proportionate increase, overall numbers of lone-actor attacks remain relatively low when compared to terrorist attacks generally. ${ }^{19}$ The broader community impact of these attacks is nevertheless significant when they occur. The 2019 Christchurch mosque attacks led to 51 deaths, a public out-pouring of grief, a formal review of Government processes ${ }^{20}$ increased and sustained fears within the Muslim community, ${ }^{21}$ and rapid changes to firearms legislation. ${ }^{22}$ Attacks in France and Austria in 2020 prompted community-wide concerns in Europe, an increase in the Terrorism Threat Level in the UK and international tension over the French President's reaction to the attacks.

Along with the increase in lone-actor attacks has come a change in ideological motivations. US lone-actor terrorism (as with group-based terrorism) was earlier dominated by left-wing attackers in the 1970s, with extreme right-wing ideologies emerging as an influence in the 1980s, and becoming more prominent in the final decade of the twentieth century. Right-wing extremists were responsible for 73 percent of loneactor attacks in the US to $2016^{23}$, and 87 percent of attacks in $2019 .{ }^{24}$ The prevalence of right-wing attacks is, in part, due to the domestic political context in the US, something starkly obvious during the last days of the Trump presidency in January $2021 .{ }^{25}$ Right wing attackers tend to prefer firearms (often semi-automatic weapons) ${ }^{26}$ and the open accessibility of such weapons in the US is one factor virtually without parallel elsewhere in the world and, when added to the domestic political context, creates a uniquely American phenomenon.

High US rates of lone-actor terrorism have possibly impacted the perception that lone-actor terrorism, particularly that of the right-wing, has increased world-wide. ${ }^{27}$ Spaaj (2018) reported that high rates of right-wing attacks in the US contrasted to lower levels in Europe, and EU member states reported five, one and six right-wing extremist attacks in 2017, 2018 and 2019 respectively. ${ }^{28}$ However, failed and foiled attacks are not always publicised, and this may mask increases in right-wing extremism in the EU. ${ }^{29} \mathrm{In}$ deed, the UN Security Council's Counter-Terrorism Committee reported a 320 percent increase in right-wing terrorism globally in the five years to $2020^{30}$.

With lower rates of right-wing extremism in the EU come higher rates of Islamic, leftwing and other ideological types. Significant ethno-nationalist influences are evident across the EU, ${ }^{31}$ while neo-Nazism is strong in Germany, and Islamophobia is evident in the Netherlands. ${ }^{32}$ These clear differences again reflect the importance of domestic political contexts on terrorism rates and types, with many instances in the EU being linked to dissident Republican groups in Northern Ireland, and separatist terrorist groups in Spain $^{33}$. 
Islamic lone-actor extremists have also been prominent internationally in the past 20 years. From the late 2000s, al-Qaeda strongly encouraged this method of terrorism, and Islamic State (IS) did the same from the 2010s, ${ }^{34}$ with numbers of related attacks more than doubling in the US in the past decade, ${ }^{35}$ with a peak of 53 deaths in the US in 2016. ${ }^{36}$ Increases were also seen in Europe where all terrorist fatalities in 2018 and 2019 were from Islamic-extremist attacks. ${ }^{37}$ France in particular has experienced multiple Islamist inspired terror attacks - from small groups and lone-actors - since 2012, reaching a high point in 2014-2015 with lone-actor attacks continuing each year up to and including 2021.

With the decline of al-Qaeda's global influence following Osama bin-Laden's death and the latter decline of IS, ${ }^{38}$ Islamic-extremist attacks appeared to decrease. ${ }^{39}$ The lack of overt power held by al-Qaeda and IS lowered their ability to encourage lone-actor attacks internationally. In 2018, IS only claimed one attack in Australia, and did not claim any in the US..$^{40}$ In 2019, four deaths in the US were attributed to Islamic extremists. ${ }^{41}$ This decline may revert as other groups seek to fill the power-vacuum left by IS, ${ }^{42}$ if al-Qaeda again rises to power following a period of regrouping, or if IS continues to gain strength via its global provinces and affiliates. ${ }^{43}$ Both groups are considered to still pose a threat to the West. ${ }^{44} \mathrm{~A}$ rapidly occurring, albeit short, resurgence in Islamist attacks was prompted in October 2020 by a history teacher showing a cartoon image of the Prophet Mohammed, which underscores the latent risk that continues from this source..$^{45}$

Battersby has explained New Zealand's terrorism context as nuanced and quite different to that of other countries. ${ }^{46}$ "Terrorism here has been generally less frequent and less severe than elsewhere, at times emulating overseas trends and at other times germinating its own particular causes." ${ }^{\prime 7}$ Battersby notes the impact of the era of modern terrorism was experienced with several bomb threats, bombings, and fire bombings in the early 1970s, and again during the controversial Springbok Tour in 1981. These were, however, the only two occasions when any genuine sequentially planned bombings occurred. Otherwise, New Zealand's experience of such violence was more in the form of occasional, unconnected events almost entirely undertaken by lone-actors. While the rest of the world has seen a perceptible increase in lone-actor perpetrators, for New Zealand this mode has been its norm. ${ }^{48}$

There has been a lack of awareness of terrorism risk in New Zealand due to perceptions that its frequency and severity has been less, and that the country was protected from international influences by its size and geographical isolation. ${ }^{49}$ This attitude is reflected in a general lack of attention by successive governments on the subject. ${ }^{50}$ Until February 2020 New Zealand lacked a formal counter-terrorism strategy, and the Royal Commission of Inquiry into the Terrorist Attack on Christchurch Mosques (RCOI) observed a clear lack of centralised leadership in the nation's approach to countering terrorism. ${ }^{51}$ The only open-source Government report that dealt with terrorism generally prior to 
March 2019 was the 2016 Cullen and Reddy review of intelligence and security. ${ }^{52}$ While this review reported that New Zealand was not immune to extremist activity, it did not assess the risk of terrorism, much less the risk of lone-actor terrorism, the capability or intent of at-risk individuals, or what influenced individuals' engagement in terrorism. ${ }^{53}$

A number of instances in recent years highlight the risk (and indeed the 15 March 2019 attacks demonstrated the reality of it) that there is an on-going realistic possibility of lone-actor attacks occurring in New Zealand. ${ }^{54}$ In 1981, Christopher Lewis made an unsuccessful attempt to assassinate Queen Elizabeth II who was visiting New Zealand. In 1982, Neil Roberts conducted a suicide bomb attack against the Wanganui Police computer centre. Threats made in 2003 to poison public utilities during the America's Cup regatta and the Tiger Woods visit may have been the work of a lone-actor or actors (albeit as threats rather than acts). The 2014 threat to contaminate baby formula which prompted unprecedented security precautions was the work of a single individual acting alone. He was convicted and sentenced to eight years imprisonment for criminal blackmail, his actions not meeting thresholds in the Terrorism Suppression Act, despite them being described as terrorism, or akin to it, by various observers. ${ }^{55}$

The emergence of al-Qaeda did not appear to resonate in New Zealand, but the emergence of IS and its dissemination of propaganda on social media platforms did inspire a response from New Zealanders. A few travelled to war-zones, the most well-known of whom, Mark Taylor, posted a YouTube video calling for sympathisers in New Zealand to attack 2015 ANZAC Day commemorations. In 2016, Imran Patel was the first person in New Zealand to be charged for possession and distribution of objectionable material displaying extreme violence, material produced by IS that had been banned under the Film, Video and Publications Classification Act. ${ }^{56}$ Patel's three-year nine-month sentence was in addition to a previous sentence he served for threatening to kill a taxi driver in the name of Allah. ${ }^{57} \mathrm{He}$ acted alone and did not appear to have any formal links to IS. ${ }^{58}$ On the same day Patel was sentenced, Niroshan Nawarajan received five months home detention for possession of objectionable material, displaying extreme violence. ${ }^{59}$ Nawarajan had walked into a US Consulate wearing an IS $t$-shirt asking if the building was bomb-proof, while in possession of a hard-drive containing extremist content. ${ }^{60}$

In July 2017, a Christchurch teenager previously engaging with online IS content threatened to kill people in a Christchurch mall while brandishing a stolen metal pole. His initial intent reportedly was to obtain a motor vehicle and drive it into a crowd of people. He faced charges of robbery, assault, possession of offensive weapon, threats to kill, disorderly behaviour and intentional damage ${ }^{61} \mathrm{He}$ was reportedly suffering from Post-Traumatic Stress Disorder. Overseas studies have noted the common occurrence of mental health problems among lone-actor terrorists. ${ }^{62}$ In early 2018, Jordayne Madams received six months community detention for possessing IS propaganda and child sex abuse material. ${ }^{63}$ Media articles noted that he suffered from Asperger syndrome. ${ }^{64}$ 
Although not reported publicly at the time, in February 2019 (a month before the Christchurch attacks), police apprehended a teen who had acquired firearms, constructed improvised explosive devices and posted intentions on-line to commit a mass killing at a South Island school. No details were provided regarding what, if any, particular ideology motivated the teen, but he had described himself as a 'terrorist', selected a target for his attack and had undertaken planning for it. ${ }^{65}$ No statement regarding his mental health was released.

More recently, a 15 year old from Porirua was identified by the FBI after engaging online making disparaging remarks about Muslims and Arabs, and discussing with another user about his planned mass shooting attack. He reportedly stated that his purpose was to "recruit people and to complete....the mission" commenced by Tarrant. Following his arrest, and on first engaging with the Youth Court the youth was noted as being 'very anxious' but no other information concerning mental health was revealed. ${ }^{66}$

On 15 March 2019, Tarrant attacked two Christchurch mosques, resulting in the deaths of 51 people. Tarrant's background is typical of a lone-actor, being marked by social isolation, ideological adherence and trauma. His background includes: his parents' separation, an abusive step-father, his father's suicide, his own racist ideas and ideological beliefs, few friends and social anxiety, bullying, heavy internet use and online gaming, and few protective factors. His attacks were well-planned and, due to his social isolation, there was little opportunity for leakage. ${ }^{67}$ No formal mental health diagnosis has been published but Tarrant stated to his sister he thought he was autistic and a sociopath. In addition, Tarrant travelled extensively, ${ }^{68}$ did not seek higher education, ${ }^{69}$ and donated funds to white identitarian organisations ${ }^{70}$.

As a result of Tarrant's attacks, New Zealand's National Terrorism Threat Level was elevated to 'high', and then lowered to 'medium' in April 2019. ${ }^{71}$ Prior to this, the level had been at 'very low' or 'low' for a number of years. ${ }^{72}$ This threat level is assessed by the Combined Threat Agency Group (CTAG) based on a considered analysis of a range of factors, including 'watch-lists' of suspects, maintained by New Zealand's security agencies. $^{73}$ Prior to March 2019, the bulk of these individuals were considered radicalised (or at risk of being radicalised) by IS-inspired ideology. ${ }^{74}$ Following the Christchurch attacks, however, security agencies significantly increased the number of those they were 'watching' to include more who were considered to have Right Wing Extremist, Neo Nazi or white supremacist views. ${ }^{75}$ This expanded the overall number of individuals being monitored. Previously, security agencies may have been able to more readily identify, triage and prioritise suspects due to low numbers of suspects being considered. However, with the changed threat level, increase in the number of watchlist suspects and the diversification of threat type, a much more systematic, consistently deliberate, and evidence-based approach will now be required. 
With the new global attention on lone-actor terrorism, and the clear and obvious increase in it as a mode by which terrorist organisations, groups, loose associations and individuals carry out their operations, there has been a growing interest among academics and counter-terrorism practitioners in this type of terrorism. Of particular note has been a number of academic studies of lone-actors to see what common traits they have previously exhibited in an endeavour to discover if such traits are observable or discoverable prior to their attack. With watchlists globally increasing, the value of such endeavours is obvious. New Zealand has an intermittent but lengthy history of lone-actors and, as covered above, the present and future risk they pose has not abated.

\section{Existing Lone-actor Research}

Eight significant international studies analyse a range of lone-actor terrorist characteristics or indicators and bring considerable depth to the endeavour of understanding lone-actor terrorism. Other research in this aspect of the lone-actor field tends to be a literature review re-summarising these eight studies, or focuses on single behavioural dimensions limiting detection of behavioural patterns. ${ }^{76}$ The variety of indicators and study methodologies complicates comparisons between the eight studies, ${ }^{77}$ and identification of significant indicators. ${ }^{78}$

The eight studies all draw their samples from Europe, the US, or both, with a heavy emphasis on the US. Depending on collection methodology, dates included fall anywhere between 1940 and 2018, and sample sizes range from 98 to 461. Spaaj and Haam's sample is based on US attacks only, and the collection date commenced at 1940. They identified 38 lone-actor attacks prior to 2001, and the majority of these occurred from 1958 onwards. Overall, they considered 123 lone-actor terrorists, and collected information from a wide variety of sources. Schuurman et al's (2018) sample is based on the US and Europe from 1978-2015, but only considered 55 lone-actor terrorists. Their collections were based on a much narrower range of sources. Gruenewald et al's (2015) sample is based on incidents from 1980 onwards, due to collection methodologies of the American Terrorism Study (ATS), created with the FBI. While methodologies are routinely explained in published research, it is sometimes unclear why some data was included or excluded. Collection methodologies of the Empirical Assessment of Domestic Radicalization (EADR) project are not outlined. The project achieved a large sample size, based solely on US terrorists - 1,473 overall, including 461 lone-actor terrorists, from 1940 onwards. Despite the unclear methodology, the results mirrored those of other studies. There is also some cross-pollination between studies, with the US National Institute of Justice (NIJ) sponsoring research by Gill, Horgan and Deckert (2014), and Meloy (2016). ${ }^{79}$

While Gill, Horgan and Deckert (2014) considered most relevant indicators, they relied on media reporting. They considered multiple indicators across 119 individuals, from the US and Europe, from 1990-2013. Gill stands out as a preeminent researcher of 
lone-actor terrorism indicators ${ }^{80}$ - he was an early researcher of lone-actors, utilises his own database and codebook, has published numerous studies, and is often quoted in other research. ${ }^{81} \mathrm{He}$ continues to publish yearly, often with a slightly different focus. Indeed, various research limitations complicate accurate identification of lone-actor terrorism indicators. Some research, such as that by Gallagher (2017), conflates indicators affecting both general and lone-actor terrorists. The age of data in some studies does not reflect recent changes in the lone-actor terrorism context, and this limitation must be noted in current research. Indeed, while lone-actor terrorism is no longer considered an under-researched topic internationally, ${ }^{82}$ more studies employing current empirical data are required.

Despite the variety of indicators and methodologies used in the eight studies, analysis determined that similar conclusions were drawn in each study. In addition, all studies considered distal characteristics and proximate behaviours, ${ }^{83}$ which are relevant in lone-actor assessments. Distal characteristics are chronic aspects of an individual which may prompt monitoring, while proximate behaviours are patterns rather than discrete variables, and encourage active risk management of an individual. ${ }^{84}$ Overall, the similarities in indicators across these studies allowed for closer analysis of their relevance. Indicators that featured consistently across studies are plotted in Table One below for comparison purposes, and to further analyse the significance of each in identification of lone-actor terrorists. Some indicators were able to be combined for this analysis. Gaps indicate that an indicator was not considered by the study.

Table One: Database comparison of lone-actor indicators..$^{85}$ (Percentages indicate the prevalence of the indicator detected in the study's lone-actor sample.)

\begin{tabular}{|c|c|c|c|c|c|c|c|c|c|}
\hline Indicator & Summary & Meloy & CLAT Project & Gill, Horgan, Deckert & Spaaj \& Hamm & Gruenewald & Schuurman & Smith & EADR/PIRUS \\
\hline \multicolumn{10}{|l|}{ DISTAL } \\
\hline Gender & Male & & & Male & Male & Male & & Male & Male \\
\hline Age & $30 \mathrm{~s}$ & & 29.7 & Over 30 & 31 & $30 \mathrm{~s}$ & & & 20s-30s \\
\hline Personal grievance & Yes & $78 \%$ & $43 \%$ & & Yes & & & $80 \%$ & \\
\hline Online dependence & Yes & $49 \%$ & & $68 \%$ & Yes & & & & \\
\hline Social isolation & Yes & & $29 \%$ & $53 \%$ & & Yes & Yes & $51 \%$ & \\
\hline Mental health & Highly-likely & $41 \%$ & $35 \%$ & $31 \%$ & $40 \%$ & & Yes & Yes & $31 \%$ \\
\hline Education & Normal to high & & & Even & Varied & High & & Higher & UNK \\
\hline Unemployment/issues & Yes & $55 \%$ & & $40-63 \%$ & $73 \%$ & & & $38-71 \%$ & \\
\hline Prior criminal & Highly-likely & $30 \%$ & $33 \%$ & $41 \%$ & $60 \%$ & & $46 \%$ & $55 \%$ & $50 \%$ \\
\hline Drug/alcohol abuse & Possible & & & $23 \%$ & & & & & $20 \%$ \\
\hline \multicolumn{10}{|l|}{ PROXIMATE } \\
\hline
\end{tabular}


Key findings of Table One are that lone-actor terrorists from Europe and the US:

- are overwhelmingly male

- $\quad$ are usually aged in their 30 s

- always hold a radical ideology

- probably suffer a personal grievance

- are dependent on the internet

- are socially isolated

- usually have intimacy issues

- often have mental health problems

- have average to high education levels ${ }^{86}$

- often suffer employment problems

- often have a prior criminal history

- probably do not have drug and alcohol problems

- will likely experience an event that 'triggers' their intent to commit an attack,

- are highly-likely to 'leak' their intent.

This table highlights that the above indicators (except for drug and alcohol use) were found to be consistently relevant and prominent across studies. It is note-worthy that some typically-cited indicators, such as mental health and social isolation, can be less common in lone-actors than other factors, such as having a personal grievance or intimacy issues.

\section{The New Zealand Context Compared}

Seven of the New Zealand cases noted above align with the definition of terrorism and provide sufficient detail to allow for deeper analysis. By placing these cases adjacent to findings from the international comparison table (Table One), their characteristics can be compared. The results are presented in Table Two, overleaf.

Key findings of Table Two are:

- the sample is younger on average than Table One would suggest

- all have a radical ideology

- internet influence was less than expected

- social isolation was less than expected

- mental health problems were higher than expected,

- leakage was either unknown or less than expected.

While the small number of New Zealand cases means the above findings are suggestive only, this table highlights initial differences between the New Zealand and international samples. Some of the differences - particularly internet influence and social isolation - could be attributed to the age of three cases (being pre-internet). The high mental 
health rates could be attributed to known higher rates of mental health disorder in the general New Zealand population, compared to overseas. ${ }^{87}$ While there are still similarities between the two samples, it is also possible that the New Zealand context is somewhat different to those overseas. Although there are various gaps in the below table that could be enhanced by classified information, ${ }^{88}$ the New Zealand-specific results could aid better understanding of the domestic lone-actor context.

Table Two: New Zealand cases and New Zealand summary, vs summary of international database comparison.

\begin{tabular}{|c|c|c|c|c|c|c|c|c|c|}
\hline Indicator & Intl. Summary & B. Tarrant & C. Lewis & N. Roberts & J. Madams & I. Patel & N. Nawarajan & Suppressed & NZ Summary \\
\hline \multicolumn{10}{|l|}{ DISTAL } \\
\hline Age & $30 \mathrm{~s}$ & 28 & 17 & 22 & 18 & 26 & 26 & 17 & $17-28$ \\
\hline Personal grievance & Yes & Yes & UNK & Yes & Unlikely & UNK & UNK & UNK & Likely \\
\hline Online dependence & Yes & Yes & N/A & $\mathrm{N} / \mathrm{A}$ & Likely & Unlikely & Unlikely & Yes & Likely \\
\hline Social isolation & Yes & Yes & Yes & No & UNK & No & No & Yes & Possible \\
\hline Mental health & Highly-likely & Possible & Yes & Yes & Yes & Yes & UNK & Yes & Highly-likely \\
\hline Education & Normal to high & Normal & No & Normal & UNK & UNK & UNK & Low & Unclear \\
\hline Unemployment/issues & Yes & Yes & Yes & No & UNK & UNK & UNK & UNK & Unclear \\
\hline \begin{tabular}{|l|} 
Prior criminal \\
\end{tabular} & Highly-likely & No & Yes & Yes & No & Yes & UNK & UNK & Likely \\
\hline Drug/alcohol abuse & Possible & UNK & UNK & UNK & UNK & UNK & UNK & UNK & UNK \\
\hline \multicolumn{10}{|l|}{ PROXIMATE } \\
\hline
\end{tabular}

Understanding New Zealand's context can be further enhanced through analysis of Police data relating to a lone-actor cohort. In Table Three (overleaf) permission was obtained to use anonymised Police data of suspected potential lone-actor cases ${ }^{89}$ alongside anonymised data relating to general offenders who had been charged with serious violence offences in the five years to December 2018. The comparison of the two data sets tests that the characteristics identified in the lone-actor cohort are unique. Including such a control group is widely recommended by researchers to enhance study strength ${ }^{90}$.

Analysis of this table highlights several similarities between the two data sets. Rates of overall prior criminal offending are similar, as are the rates of prior violent offending. In addition, a third of both groups have prior drug offending and nearly 10 percent have prior sexual offending. However, a greater proportion of violence offenders have prior dishonesty offending than the lone-actor cohort. ${ }^{91}$

On the other hand, there are also notable differences between the two groups. The New Zealand lone-actor cohort has a higher rate of prior firearms alert/offence (31 percent vs 14 percent) and a higher rate of holding firearms licences ( 17 percent vs 1.2 percent). While the difference is possibly more representative of Police collection methodologies, 
it should be considered that possible lone-actors may be more likely to be in possession of a firearm, or to be a standing firearms licence holder. Importantly, firearms licence information is usually held by Police, and can facilitate greater depth of analysis.

Table Three: Characteristics of lone-actor cohort vs serious violence offenders.

\begin{tabular}{|l|c|c|}
\hline & Lone-actor cohort & Serious violence offenders \\
\hline Prior criminal offending & $75 \%$ & $79 \%$ \\
\hline Prior violence offence or alert & $44 \%^{92}$ & $41 \%^{93}$ \\
\hline Prior firearms offence or alert ${ }^{94}$ & $31 \%$ & $14 \%^{95}$ \\
\hline Firearms licence holder ${ }^{96}$ & $17 \%$ & $1.2 \%$ \\
\hline Prior drug offending & $37 \%$ & $35 \%$ \\
\hline Prior dishonesty offending & $48 \%$ & $55 \%$ \\
\hline Prior sexual offence or sex offender alert ${ }^{97}$ & $9 \%$ & $8.5 \%$ \\
\hline Mental health ${ }^{98}$ and/or suicidal tendencies & $29 \%$ & $19 \%$ \\
\hline Mental health only & $14 \%$ & $7 \%$ \\
\hline Family violence involvement ${ }^{99}$ & $66 \%$ & $92 \%$ \\
\hline Age & $25-55$ & $19-35$ \\
\hline Female (gender) & $3 \%$ & $18 \%$ \\
\hline Ideology & Yes & $\mathrm{N} / \mathrm{A}$ \\
\hline
\end{tabular}

In addition, there is a significant difference in the mental health/suicide figures, with this number being much higher for possible lone-actors. When looking only at mental health, there is still a significant difference, with 14 percent of possible lone-actors suffering mental health problems, compared to only seven percent of serious violence offenders. Despite the differences between data sets, this figure is much lower than international findings. One explanation for this is the preliminary lone-actor data requires further Police assessment. A second possibility is Police recording of mental health problems could be inconsistent and subjective. If the finalised list of subjects underwent a formal assessment, this figure could be much higher, especially given higher rates of mental health disorders observed in New Zealand generally.

There are also key demographic differences between the two sets of offenders. There was a broad age range present for possible lone-actors, but on average they were older, with the majority being aged 25-55 years. This aligns with international research also noting that they are typically older than general terrorists. ${ }^{100}$ The serious violence offenders tended to be younger with the majority being aged 19-35 years. There is a visible bell-curve amongst the violence offenders, which peaks at 20-30 years. The gender of the possible lone-actors also aligns with research, which notes that the majority of such individuals are male. 
Unfortunately, the Police data cannot be compared to the earlier international database table because it does not include intricate indicators, such as being socially isolated or having employment problems. Indeed, while prior criminal, violence or firearms offending could be an indication that an individual may possibly engage in a lone-actor event, these indicators need to be present alongside other relevant indicators for thorough assessment. Despite this weakness, comparison of the lone-actor cohort and serious violence offenders succeeded in introducing a control group and differentiating characteristics of the two groups. The use of this comparison indicates that, with the application of appropriate methodology, analysts could better differentiate between possible lone-actors, general offenders and other members of the community.

\section{Applicability of International Lone-actor Research to New Zealand}

A lone-actor terrorist profile cannot be developed, ${ }^{101}$ nor can a perfect combination of risk factors be compiled. However, research in this paper could be applied immediately by New Zealand security agencies in developing an evidence-based framework that informs current priorities of identification, prevention and management of possible lone-actor terrorists.

Analysis of the eight international studies, New Zealand Police data on possible lone-actors, similar data on serious violence offenders, and New Zealand case studies has enabled the identification of indicators that could inform a framework supporting lone-actor prevention activities. Despite the absence of a lone-actor profile, research does identify unique characteristics of lone-actors. ${ }^{102}$ Indeed, the comparison of the two Police data sets supports this by highlighting differences between what could otherwise be similar cohorts. Importantly, without an ideology, other violence offenders do not undertake the same decision-making process as lone-actors. ${ }^{103}$ For the most part, the incorporation of New Zealand data reinforces international findings, but is weakened by small sample sizes and possibly Police collection methodologies. Therefore, international studies must provide the basis of an evidence-based framework for New Zealand. The following sub-paragraphs describe, in more detail, some of the more prominent indicators that would provide an evidence-base for any framework applied by local security agencies.

\section{Ideology}

A key defining characteristic of lone-actor terrorists is that they hold an ideology, even though the ideologies themselves may differ. ${ }^{104}$ This is clear from international research and New Zealand case studies, as well as the Police lone-actor cohort. The range of possible ideologies highlights that analysts must be cognisant of an attack being motivated by a range of ideologies. ${ }^{105}$ While individual management plans for each ideology could be suggested, ${ }^{106}$ this would be overly-complicated, and is not necessary given overall similarities in lone-actor characteristics across ideologies. ${ }^{107}$ 
Importantly, an individual's ideology may be weak, or new. Many lone-actor terrorists are not devoutly religious and are not highly-connected to the community of their ideology. ${ }^{108}$ Recent converts posing a lone-actor terrorism risk have been seen in New Zealand, Australia, ${ }^{109}$ and elsewhere. ${ }^{110}$ Of note, in 2012, Spaaj suggested it may be difficult to identify an individual's ideology, despite them being a possible lone-actor. While analysts should be aware of this, to differentiate a possible lone-actor from a regular violence offender, it is possible that increased internet influence since 2012 has encouraged more people to openly espouse their ideology.

\section{Social isolation}

More than half of lone-actor terrorists are considered socially isolated, and to have online dependence. Despite this, many researchers insist that no one is truly a lone-actor, or socially isolated, particularly with increased internet connectivity. It is acknowledged in other research that truly independent radicalisation to violence is rare. ${ }^{111}$ Many individuals receive ideas, encouragement or training from online peers and material. ${ }^{112}$ Indeed, the influence of the internet on terrorism has increased dramatically in the past decade, impacting rapid change to the lone-actor terrorism context. ${ }^{113}$ However, while appearing to provide a means of connectivity, online dependence can mask true social isolation from family and friends. Furthermore, the internet provides anonymity, ${ }^{114}$ and is possibly why so much leakage occurs online $\mathrm{e}^{115}$.

The definition of 'lone-actor terrorist', followed in this research and by related researchers, notes that lone-actor terrorism can include individuals or small cells. By this definition, the term lone-actor is not limited to truly isolated individuals, such as the deliberately hermitic Unabomber Theodore Kaczynski. ${ }^{116}$ Rather, social isolation infers that an individual is disconnected from family or peers, and probably spends significant amounts of time online. Consequently, social isolation, the inability to form meaningful relationships, and rejection from mainstream society, can be primary drivers for an individual to feel deprived of what they deserve, develop a personal grievance, and commit an act of violence. ${ }^{117}$ It can be considered that an individual has a "lack of prosocial influences", emphasising that they do not have positive balancing relationships. This term aligns with psychological analysis. As such, if the majority of an individual's activities are committed alone, and they did not receive meaningful operational support from disconnected groups or individuals, they should be considered a lone-actor. ${ }^{118}$

\section{Personal grievance}

Having a personal grievance is particularly notable in lone-actor terrorists, and is an important attack motivator. ${ }^{119}$ While only four of the international studies specifically reported on this, lone-actor literature in general considers personal grievance an important characteristic of lone-actors. ${ }^{120}$ Indeed, where known, this also featured highly in the New Zealand case studies. Such a grievance may develop following identification 
with a political grievance, ${ }^{121}$ or from a perceived personal injustice such as bullying. ${ }^{122}$ Group grievances can morph into personal ones, with lone-actor terrorists often acting in the name of a wider group of people who they want to bring justice to ${ }^{123}$ such as anti-abortionist and Atlanta Olympic bomber Eric Rudolph. ${ }^{124}$ These grievances can lead an individual to online dependence, as they may find sympathisers in this space more easily than in their day-to-day life. ${ }^{25}$

\section{Mental health}

Mental health disorders can be a key indicator in determining whether an individual poses a risk of lone-actor terrorism. However, mental health disorders must be assessed alongside other relevant indicators, and not by themselves. The effect of mental health disorders on terrorism has been widely researched and debated, ${ }^{126}$ with some international studies finding that 30-40 percent of lone-actors are likely to have mental health disorders. ${ }^{127}$ Schizophrenia, delusional disorder ${ }^{128}$ and Autism spectrum disorders present highly. ${ }^{129}$ In line with this, 29 percent of individuals considered to pose a potential risk of lone-actor terrorism in New Zealand have mental health and suicide problems. Corner and Gill note that lone-actor terrorists are 13.5 times more likely to have a history of mental illness than general terrorists. ${ }^{130}$ Comparatively, only 16 percent of New Zealanders have been diagnosed with a mental health disorder at some time in their lives. ${ }^{131}$ Mental health disorders in general are likely linked to violent behaviour, ${ }^{132}$ and this is particularly the case for schizophrenia, which can be exacerbated by alcohol and drug use. ${ }^{133}$ The relatively high levels of mental health disorders amongst lone-actors suggests that mental health is a viable indicator.

Given the prevalence of mental health disorders in the community however, mental health cannot be a sole determinant of lone-actor terrorism risk. Research indicates mental health is a viable central variable for assessing lone-actor risk due to its common comorbidity with a range of other factors ${ }^{134}$ such as being socially isolated, having a criminal history, and being influenced by a broader ideological cause. ${ }^{135}$ Analysts should be mindful of such combinations of indicators when conducting analysis. Indeed, a formal diagnosis should not be necessary for incorporation of this indicator at this stage in analysis, ${ }^{136}$ but should be included in latter stages of possible lone-actor management.

\section{High education vs low employment}

While poor employment levels can be a strain for many potential lone-actors, many also have normal to high education levels, ${ }^{137}$ and this misalignment can prove a further strain. International research coded unemployment or employment problems as present in 40-70 percent of cases. Despite the differing methodologies used, the relatively high numbers indicate that unemployment is a significant indicator. ${ }^{138}$ Unemployment, frequently moving between jobs, or a recent dismissal, can contribute to an individual feeling alienated and frustrated, and can thus contribute to personal grievances, influ- 
enced by an ideology, and a desire to commit an attack. ${ }^{139}$ Furthermore, it is possible that a parent's unemployment status can contribute to a child developing right-wing extremist views. ${ }^{140}$ Indeed, Spaaj (2015) suggests that lone-actors holding right-wing and anti-government ideologies are often from lower socio-economic communities, and are less educated.

\section{Prior criminal history}

An individual having prior criminal history is a significant indicator for lone-actor terrorism. International research suggests 30-60 percent of individuals will have a prior criminal history, with New Zealand case studies and Police data supporting this. The variation in the international research statistics is again due to differing methodologies. Meloy (2016) specifically looked at criminal violence history, as opposed to criminal history in general, while the CLAT project considered individuals who had convictions. Other studies do not break down to criminality type ${ }^{141}$ while Gill, Horgan and Deckert (2014) include people who have committed various offences, from serious violence to graffiti and drunk-driving. Regardless, all the figures are higher than the general population, with estimates that around 25 percent of New Zealand adults have a criminal conviction. ${ }^{142}$ Indeed, Jensen and LaFree (2016) suggest that individuals who participate in any kind of criminal offending are more likely to be involved in lone-actor terrorism. This correlates with the New Zealand Police data that suggests 75 percent of possible lone-actors have prior criminal offences. Therefore, it is highly-likely that possible lone-actors in New Zealand will have had prior contact with Police, which will facilitate identification by analysts.

\section{Drugs \& alcohol}

Drugs and alcohol did not feature highly in international research, with only two studies considering this, placing its prevalence at 20 percent. There was insufficient data in the New Zealand case studies to assess this, however Police data on potential cases recorded prior drug offending at 37 percent. This indicator may be worthy of further New Zealand-specific analysis due to the high rate in Police data compared to little acknowledgement in international research. Jensen and LaFree (2016) specify that prior criminal offending, which can lead to subsequent lone-actor attacks, can include drug offending. However, other research indicates that lone-actor terrorists are unlikely to attack while impaired as this may negatively impact their capability. ${ }^{143}$

\section{Intimate relationship problems}

In the international studies, the prevalence of intimate relationship problems ranged from 37 to 84 percent. While differences were due to varying definitions, including individuals simply being single, or having relationship problems, the overall prevalence underscores the significance of this indicator. However, problems with intimate rela- 
tionships and sexually deviant behaviour were not sufficiently explored in most studies, and many studies did little more than note that attackers were likely to be single. ${ }^{144}$ This is despite failure to form adult attachments being a key predictor of future violence. ${ }^{145}$ Indeed, lone-actor terrorists are more likely to have never been married, or to have been divorced or widowed, and to live alone. ${ }^{146}$ Spaaj (2017) notes that romantic relationship problems can be the catalyst for publicly violent attacks, and that some political violence can begin with attacks on partners. For example, Omar Mateen battered his wife and Anders Breivik was known to hate women. ${ }^{147}$ While most socially isolated individuals will also be single, others may not be socially isolated, but may struggle with intimate relationships.

In New Zealand, some relevant individuals known to Police are heavy consumers of pornography, including Madams, who was in possession of child sex-abuse images. ${ }^{148}$ Although this aspect received little attention in international research, Meloy (2016) referred to this in his Terrorism Radicalization Assessment Protocol (TRAP-18). Meloy (2016) notes that this behaviour may substitute for the absence of a sexual pair bond, and could be rationalised by an individual's ideology. In their sample, Horgan, Gill, Bouhana, Silver and Corner (2016) note that some prior criminal offences included child pornography possession. These findings indicate that pornography use should be incorporated in this broad indicator.

\section{Leakage}

Studies strongly suggest that most lone-actor terrorists will leak their attack intent to someone else, with some studies noting that individuals will communicate the threat directly to victims. Most studies state that $64-86$ percent of individuals will leak their intent, with only one study putting the number as low as 46 percent. Leakage provides security services with significant identification opportunities. However, Pantucci and Ellis (2016) note that in 35 percent of cases leakage only indicated that an individual was an extremist, not that they wanted to commit an attack. In addition, how and to whom leakage occurs differs depending on ideology ${ }^{149}$ Gill, Horgan and Deckert (2014) on the other hand reported that in 60 percent of cases a letter or public statement would be produced. Even more significantly, in 63 percent of cases the offender would directly tell associates of their attack plans. ${ }^{150}$ Indeed, despite the prevalence of social isolation amongst lone-actors, they often maintain some relationships with family members, ${ }^{151}$ and it is often these family members who are privy to leakage. ${ }^{152}$ The New Zealand case studies did not provide sufficient information to enable comparative assessment.

While lone-actor terrorists may be more difficult to identify due to the solitary nature of their activities, ${ }^{153}$ the high likelihood of leakage highlights that detection via associates will often be possible. This also highlights the importance of security services building trust and confidence with various 'communities' to promptly be informed of risk. With the higher prevalence of online connectivity, it is likely that substantial leakage will 
occur online, providing a further detection avenue. A motive for lone-actor terrorists to leak their intent is that it provides them with an opportunity to have their grievance heard. ${ }^{154}$ Leakage may be intentional or unwitting, may occur due to long lead-in times to attacks, ${ }^{155}$ and may be due to unsophisticated operational security measures. ${ }^{156} \mathrm{Im}$ portantly, possible lone-actors will not always have actual intent, even when they leak threats. ${ }^{157}$ While empty and real threats can be difficult to differentiate, ${ }^{158}$ incorporating other indicators will enable more accurate analysis.

\section{Capability}

Capability is another difficult factor to analyse, ${ }^{159}$ but is the next step after determining an individual is both engaged in a radical ideology and has intent to attack ${ }^{160}$. Without appropriate capability, it is unlikely that a lone-actor would succeed in their endeavour. A possible explanation for the difference internationally in the high number of extremists and the conversely low number of lone-actors, as well as the number of failed attacks, is that lone-actors are unable to develop requisite capability levels. ${ }^{161}$ Becker (2014) highlights that by virtue of operating alone, lone-actors lack shared skills, accesses, expertise and knowledge, resulting in less-lethal attacks.

However, while a large, coordinated attack would require high capability levels, rudimentary attacks over the past few years have demonstrated that low-capability attacks can still achieve lone-actor terrorist aims. ${ }^{162}$ These attacks will often be committed using rudimentary weapons such as knives or vehicles, as far less training and preparation are required. ${ }^{163}$ For example, in 2014 in Canada two military members were killed when Martin Couture-Rouleau hit them with a vehicle ${ }^{164}$ and in 2017 in London, Darren Osborne drove a van into a group of Muslims. ${ }^{165}$ Such rudimentary attacks allow lone-actors to bridge gaps between high-intent and low-capability levels. ${ }^{166}$

While technical capability is a consideration for analysts, they must also consider the psychological resources that enable a lone-actor to attack. ${ }^{167}$ Indeed, an individual must overcome natural human resistance to committing extreme violent acts. ${ }^{168}$ Such barriers can be overcome through viewing extremist material for desensitisation, internalisation of extremist ideology, ${ }^{169}$ or socialisation with relevant associates. ${ }^{170}$ Importantly, a weak ideology may not allow them to overcome such barriers as they may determine that the cost of conducting an attack is too high. ${ }^{171} \mathrm{~A}$ further complication is that true capability is subjective. While an individual may not appear to have sufficient capability for an attack, a self-perception of high capability could be enough to maintain attack motivation. ${ }^{172}$

Analysts must conduct capability assessments on possible lone-actors to differentiate between individuals who want to conduct an attack, and those who are actually able to do so. ${ }^{173}$ The conclusion may determine whether an individual requires passive or active management by security agencies. Schuurman and Eijkman (2018) emphasise that false 
positives of likely attackers can be avoided through adept analysis of both intent and capability. Analysts must consider skills, knowledge, training, and possession of relevant material. Despite its centrality in assessing real threat, capability lacks sufficient attention in related research, ${ }^{174}$ likely due to the multiple variables possible, and the indicator's dynamic nature.

\section{Protective Factors}

Protective factors are also an important consideration in assessing the threat of a possible lone-actor. Protective factors can counter or balance risk factors, and can encourage an individual to live a more prosocial life. ${ }^{175}$ These factors can include individual, peer, and family factors, ${ }^{176}$ such as having an intimate relationship, a traditional family, conventional employment, social orientation, and self-control. ${ }^{177}$ While some protective factors are the opposite of risk factors, they should not routinely be considered as such. ${ }^{178}$

Despite their positive impact and influence on an individual's assessment, protective factors are a relatively new, under-researched concept. ${ }^{179}$ Of the significant studies considered for this research, only Gill (2015) mentions protective factors, but even he has not analysed these more than suggesting what might constitute a protective factor. However, as of 2018, the US National Institute of Justice (NIJ) had sponsored research to identify relevant protective factors, ${ }^{180}$ and, as of 2019 , NIJ was looking to further research in this area. ${ }^{181}$ Despite the lack of research, it is vital that they are included in analysis because they do influence an individual's actions, and ignoring them could potentially lead to confirmation bias. ${ }^{182}$

\section{Weightings}

Weightings or scores should not be applied to indicators in lone-actor terrorism threat assessments. ${ }^{183}$ Perceived benefits of weightings are the guidance provided to lessexperienced analysts, differentiation of more serious indicators, ${ }^{184}$ and an expedited process of overall prioritisation. However, given that even less research has been conducted on weightings than indicators themselves, and the very low base rate of loneactor terrorists, ${ }^{185}$ any numbers chosen would be close to random and not evidencebased. Furthermore, weightings are unable to account for nuances present in indicators, such as levels of dysfunction within a family or severity of mental health problems.

\section{Conclusion}

This paper demonstrates that international research on lone-actor terrorists can be combined with New Zealand data with a view to establishing an evidence-based approach for the identification of possible lone-actor terrorists in New Zealand, and preventing future attacks. While New Zealand's terrorism context necessitates efficient 
and effective identification of individuals who may pose a terrorism risk, security agencies currently conduct this task in the absence of sufficient domestic research. However, despite the apparent limitations of data regarding lone-actors in general, and especially in New Zealand, analysis throughout this research has shown correlation between numerous indicators across empirically based studies at sufficient levels for their use by local security agencies.

Eight relevant, international studies examine multi-factorial indicators of terrorism risk, and employ a variety of methodologies, sample sizes and date ranges to assess these indicators. Despite the variety, there is commonality between the relevance and prevalence of certain indicators. Following incorporation of the most prominent indicators in a comparison table, clarity was gained on which indicators could be used by security agencies.

To ensure closer alignment with the New Zealand context, the characteristics of a possible New Zealand lone-actor cohort, New Zealand serious violence offenders and seven known lone-actors were also compared. The results confirmed expected differences in characteristics between the lone-actor and serious violence offender cohorts, but also suggested differences between international and New Zealand possible lone-actors. There were, however, some similarities between the international and New Zealand groups, and overall it was determined that international findings were applicable to New Zealand.

The findings in this paper can inform current activity by New Zealand security agencies to enhance the tools and guidelines used in the identification of potential lone-actors. With the changed domestic threat level, increase in watchlist suspects and changing threat types, this paper enables security agencies in the development of a more systematic, evidence-based approach. While a lone-actor terrorist profile cannot be developed, this paper enables this approach through a description of distal characteristics and proximate behaviours, as well as protective factors, which would assist security agencies in their analysis.

Given the risk of lone-actor terrorism that New Zealand faces, and the related responsibilities of security agency analysts, this evidence-based approach, drawn from analysis of international and domestic research, will enhance analytical capability and will ultimately aid in the prevention of future terrorist acts. 
1 Gabriel Weimann, "Lone Wolves in Cyberspace", Journal of Terrorism Research 3, no. 2 (2012): 75-90; "Obama says 'lone wolf terrorist' biggest U.S. threat", Reuters 17 August 2011. Available at https://www.reuters.com/article/us-usa-obama-security-idUSTRE77F6XI20110816; Charles Lister, "Returning Foreign Fighters: Criminalization or Reintegration?", Washington, D.C., 2015. Available at https://www.brookings.edu/wp-content/uploads/2016/06/En-Fighters-Web.pdf; Ramon Spaaj, Understanding Lone Wolf Terrorism: Global Patterns, Motivations and Prevention, Springer (2012). Available at https://doi.org/10.1007/978-94-007-2981-0; Clark McCauley and Sophia Moskalenko, "Toward a Profile of Lone Wolf Terrorists: What Moves an Individual From Radical Opinion to Radical Action", Terrorism and Political Violence 26, no. 1 (2014): 69-85. Available at https://doi.org/10.1080/0954655 3.2014.849916; Jayde Walker, “An Introduction to Countering Violent Extremism”, Practise: The New Zealand Corrections Journal 5, no. 2 (2017). Available at https://www.corrections.govt.nz/resources/ research_and statistics/journal/volume_5 issue_2_november_2017/an_introduction_to_countering_violent_extremism.html; Raffaello Pantucci, "A Typōlogy of Lone Wolves: Preliminary Ānalysis of Lone Islamist Terrorists Developments in Radicalisation and Political Violence.” ICSR The International Center for the Study of Radicalisation and Political Violence, no. March (2011). Available at https://doi. org/http://icsr.info/2011/04/a-typology-of-lone-wolves-preliminary-analysis-of-lone-islamist-terrorists/.

2 "'Self-radicalised' Kiwi most likely cause for NZ terror threat alert, intelligence expert says", Stuff. co.nz 3 November 2016. Available at https:/www.stuff.co.nz/national/politics/86059036/domestic-terrorist-incident-threat-triggered-national-security-system; "Terror threat to New Zealand revealed in security handbook"New Zealand Herald, 4 November 2016. Available at https://www.nzherald.co.nz/nz/terrorthreat-to-new-zealand-revealed-in-security-handbook/BLJGSQIK4HVKJACA6WRUIEEHMM/

3 Clark McCauley and Sophia Moskalenko, Friction, Second. Oxford University Press (2017); DHS Intelligence Enterprise, "Ideologically Motivated Lone Actors, Small Groups Pose Greatest Terrorist Threat to Homeland", Washington, D.C. (2019); Europol, "Terrorism Situation and Trend Report 2020 " (2020). Available at https://masc-cbrn.eu/masc-cbrn/europol-eu-terrorism-situation-and-trend-report-2020-released/

4 Bart Schuurman, Edwin Bakker, Paul Gill and Noémie Bouhana, "Lone Actor Terrorist Attack Planning and Preparation: A Data-Driven Analysis", Journal of Forensic Sciences 63, no. 4 (2018). Available at https://doi.org/10.1111/1556-4029.13676; Melissa Hamilton, "A Threat Assessment Framework for Lone-Actor Terrorists", Florida Law Review 70 (2018): 1319-56; Nils Böckler, Jens Hoffmann, and Andreas Zick, "The Frankfurt Airport Attack: A Case Study on the Radicalization of a Lone-Actor Terrorist", Journal of Threat Assessment and Management, 2.3-4 (2015), 153-163; McCauley and Moskalenko, Friction.

5 Paul Gill, John Horgan, and Paige Deckert, 'Bombing Alone: Tracing the Motivations and Antecedent Behaviors of Lone-Actor Terrorists', Journal of Forensic Sciences, 59.2 (2014), 425-35. Available at https://doi.org/10.1111/1556-4029.12312; Spaaj, Understanding Lone Wolf Terrorism: Global Patterns, Motivations and Prevention; Raffaello Pantucci, Clare Ellis, and Lorien Chaplais, Lone-Actor Terrorism: Literature Review (London, England, 2015); Jeanine de Roy van Zuijdewijn and Edwin Bakker, 'Analysing Personal Characteristics of Lone-Actor Terrorists Research Findings and Recommendations', Perspectives on Terrorism, 10.2 (2016), 42-49.

6 Emily Corner and Paul Gill, 'Mental Health and Terrorism', Combating Terrorism Center at West Point, 10.1 (2017); de Roy van Zuijdewijn and Bakker; Noémie Bouhana, Amy Thornton, and others, PRIME: Preventing, Interdicting and Mitigating Extremism Events: Defending against Lone Actor Extremism, 2016.

7 John Battersby, "Terrorism Where Terror Is Not: Australian and New Zealand Terrorism Compared," Studies in Conflict \& Terrorism, 41:1, (2017), 59-76. Available at https://doi.org/10.1080/105761 0X.2017.1287501

8 "Skinhead's pose potential security threat in wake of Christchurch attack - Paul Buchanan", One News, 28 March 2019. Available at https://www.tvnz.co.nz/one-news/new-zealand/skinheads-pose-potential-security-threat-in-wake-christchurch-terrorist-attack-paul-buchanan

9 Edwin Bakker and Jeanine de Roy van Zuijdewijn, Lone-Actor Terrorism Definitional Workshop, 2 (London, England, 2015).

10 Schuurman, Bakker, and others.

11 John Battersby, "The Ghost of New Zealand's Terrorism Past and Present," National Security Journal, 1:1 (2019), 35-47. Available at https://nationalsecurityjournal.nz/20190101-2/371-2/.

12 Spaaj, Understanding Lone Wolf Terrorism: Global Patterns, Motivations and Prevention; START, Patterns of Lone Actor Terrorism in the United States (Arkansas, USA, 2014); 'Lone wolf attacks are becoming more common - and more deadly', PBS, 2016. Available at https://www.pbs.org/wgbh/ 
frontline/article/lone-wolf-attacks-are-becoming-more-common-and-more-deadly/; Michele T. Pathé and others, 'Establishing a Joint Agency Response to the Threat of Lone-Actor Grievance-Fuelled Violence', Journal of Forensic Psychiatry and Psychology, 29.1 (2018), 37-52. Available at https://doi.org/10.1080/ 14789949.2017.1335762.

13 Ramon Spaaj, 'The Enigma of Lone Wolf Terrorism: An Assessment', Studies in Conflict \& Terrorism, 33 (2010), 854-70. Available at https://doi.org/10.1080/1057610X.2010.501426; Joel Capellan, 'Lone Wolf Terrorist or Deranged Shooter? A Study of Ideological Active Shooter Events in the United States, 1970-2014', Studies in Conflict \& Terrorism, 38 (2015), 395-413. Available at https://doi.org/10.1 080/1057610X.2015.1008341; Spaaj, Understanding Lone Wolf Terrorism: Global Patterns, Motivations and Prevention.

14 Daveed Gartenstein-Ross, 'What Does the Recent Spate of Lone Wolf Terrorist Attacks Mean?', War on the Rocks, 2014. Available at https:/warontherocks.com/2014/10/what-does-the-recent-spate-oflone-wolf-terrorist-attacks-mean/.

15 Worth.

16 Institute for Economics \& Peace, Global Terrorism Index 2020: Measuring the Impact of Terrorism (Sydney, Australia, 2020).

17 Gartenstein-Ross.

18 'Global Terrorism Database', 2019. Available at https://www.start.umd.edu/gtd/.

19 Spaaj, 'The Enigma of Lone Wolf Terrorism: An Assessment'; START, Patterns of Lone Actor Terrorism in the United States.

20 'How did the Christchurch gunman stay under the radar of state agencies?', Stuff.Co.Nz, 2019. Available at https:/www.stuff.co.nz/national/christchurch-shooting/111959270/how-did-the-christchurch-gunman-stay-under-the-radar-of-state-agencies.

21 'Three weeks after the Christchurch mosque attack: forgiveness, faith and fear', Metro, 2019 Available at https://www.metromag.co.nz/society/society-politics/christchurch-mosque-attack-three-weeks-onmuslims-grateful-but-scared-to-rock-the-boat.

22 New Zealand Police, 'Firearm Law Changes \& Prohibited Firearms', Police.Govt.Nz, 2019. Available at https:/www.police.govt.nz/advice/firearms-and-safety/firearm-law-changes-prohibited-firearms. 23 J. Reid Meloy and others, 'Some TRAP-18 Indicators Discriminate Between Terrorist Attackers and Other Subjects of National Security Concern', Journal of Threat Assessment and Management, 6.2 (2019); Ramon Spaaj and Chris Winter, 'The Evolving Threat of Lone-Actor Terrorism', Inside Story, 2018. Available at https://insidestory.org.au/the-evolving-threat-of-lone-actor-terrorism/; The Economist, 'Why White Nationalist Terrorism Is a Global Threat', The Economist, 2019. Available at https://www. economist.com/international/2019/03/21/why-white-nationalist-terrorism-is-a-global-threat.

24 Institute for Economics \& Peace. Whether perpetrators were affiliated with a group or were individuals was unspecified in the text, but the vast majority were probably individuals.

25 Spaaj, 'The Enigma of Lone Wolf Terrorism: An Assessment'; The Economist; Clint Watts, 'America Has a White Nationalist Terrorism Problem. What Should We Do?', Foreign Policy Reserach Institute, 2019. Available at https://www.fpri.org/article/2019/05/america-has-a-white-nationalist-terrorism-problem-what-should-we-do/.

26 Europol, Terrorism Situation and Trend Report 2020.

27 Brent L Smith and others, 'The Emergence of Lone Wolf Terrorism: Patterns of Behavior and Implications for Intervention', Terrorism and Counterterrorism Today, 20 (2015), 89-110; Bouhana, Thornton, and others; Daniel Byman, 'Is Right-Wing Terrorism Rising?', The National Interest, 2019. Available at https://nationalinterest.org/feature/right-wing-terrorism-rising-73241.

28 Europol, Terrorism Situation and Trend Report 2020.

29 Byman; Europol, Terrorism Situation and Trend Report 2019, 2019. Available at https://doi. org/10.2813/00041.

30 United Nations Security Council, CTED Trends Alert, 2020.

31 Europol, Terrorism Situation and Trend Report 2018, 2018. Available at https://doi. org/10.2813/00041; Europol, Terrorism Situation and Trend Report 2020.

32 Europol, Terrorism Situation and Trend Report 2019.

33 Europol, Terrorism Situation and Trend Report 2020.

34 Worth; Watts. 
35 Worth.

36 Institute for Economics \& Peace.

37 Europol, Terrorism Situation and Trend Report 2019; Europol, Terrorism Situation and Trend Report 2020.

38 Europol, Terrorism Situation and Trend Report 2019; Hamilton.

39 Meloy and others.

40 Europol, Terrorism Situation and Trend Report 2019.

41 Institute for Economics \& Peace.

42 Europol, Terrorism Situation and Trend Report 2019.

43 Charles Lister, 'What's next for Al-Qaeda after the Death of Hamza Bin Laden', Middle East Institute, 2019. Available at https://www.mei.edu/publications/whats-next-al-qaeda-after-death-hamza-binladen; International Crisis Group, Exploiting Disorder: Al-Qaeda and the Islamic State, 2016. Available at https://www.crisisgroup.org/global/exploiting-disorder-al-qaeda-and-islamic-state; Institute for Economics \& Peace; Australian Strategic Policy Institute, Counter-Terrorism Yearbook 2020 (Canberra, Australia, 2020).

44 Europol, Terrorism Situation and Trend Report 2020.

45 'Gruesome details emerge in beheading of French teacher who showed students Muhammad cartoons', The Washington Post (Washington, D.C., 18 October 2020). Available at https://www.washingtonpost.com/world/gruesome-details-emerge-in-beheading-of-french-teacher-who-showed-students-mohammed-cartoons/2020/10/17/9bcaeedc-107b-11eb-b404-8d1e675ec701_story.html.

46 Battersby, 'Terrorism Where Terror Is Not: Australian and New Zealand Terrorism Compared'; David Small, 'The Uneasy Relationship between National Security and Personal Freedom: New Zealand and the "War on Terror"', International Journal of Law in Context, 7.4 (2011), 467-86.

47 John Battersby, personal communication, 10 August 2020.

48 John Battersby, 'The Ghost of New Zealand's Terrorism Past and Present'.

49 'How ordinary people are radicalised online to become terrorists', Stuff.Co.Nz, 2018. Available at https://www.stuff.co.nz/national/101491681/how-ordinary-people-are-radicalised-online-to-become-terrorists; Chris Proctor, “"She'll Be Right” Factor Is Our Biggest Threat', New Zealand Security Magazine, $2018 \mathrm{https}$ ://defsec.net.nz/2018/08/01/shell-be-right-factor-our-biggest-threat/.

50 Royal Commission, Ko Tō Tātou Käinga Tēnei. Report of the Royal Commission of Inquiry into the Terrorist Attack on Christchurch Masjidain on 15 March 2019 (Wellington, New Zealand, 2020). Subsequent references will be noted as Royal Commission. See also Sheridan Webb, "From Hijackings to Right-Wing Extremism: The Drivers of New Zealand's Counter-terrorism Legislation 1977 - 2020," 3:1 (2021), 101-124. Available at https://doi.org/10.36878/nsj20210409.04.

51 Royal Commission.

52 Michael Cullen and Patsy Reddy, Intelligence and Security in a Free Society: Report of the First Independent Review of Intelligence and Security in New Zealand (Wellington, New Zealand, 2016).

53 Cullen and Reddy.

54 Cullen and Reddy.

55 Battersby, "Terrorism Where Terror is Not: Australian and New Zealand Terrorism Compared".

56 District Courts of New Zealand, 'R v Imran Patel [2016] NZDC 11454' (Auckland, New Zealand, 2016). Available at http://districtcourts.govt.nz/assets/unsecure/2016-09-20/2016-NZDC-11454-R-v-Imran-Patel.pdf; Mike Gillam, 'Expert: Only A Matter Of Time Before Terrorism Reaches New Zealand', The Investigators, 2016. Available at https:/www.theinvestigators.co.nz/news/expert-only-a-matter-oftime-before-terrorism-reaches-new-zealand; "Man sentenced over "terrorist material", New Zealand Herald, 2016. Available at https://www.nzherald.co.nz/nz/news/article.cfm?c_id=1\&objectid=11662107; 'Imprisoned NZ ISIS sympathiser's father: "they're going to make him a dangerous man", The Spinoff, 2019. Available at https://thespinoff.co.nz/society/01-07-2016/imprisoned-nz-isis-sympathisers-fathertheyre-going-to-make-him-a-dangerous-man/.

57 Robert Spencer, 'New Zealand: Muslim Screaming “Allahu Akbar” Threatens to Slit Man's Throat', Jihad Watch, 2016. Available at https:/www.jihadwatch.org/2016/05/new-zealand-muslim-screamingallahu-akbar-threatens-to-slit-mans-throat.

58 Ryan.

59 Spencer; Ryan. 
60 'Man shouted "Isis is here" in scuffle with officers', New Zealand Herald, 2016. Available at https:// www.nzherald.co.nz/nz/news/article.cfm?c_id=1\&objectid=11662149.

61 'Teen admits spree of violence at Christchurch mall', Stuff, 2017. Available at https://www.stuff. co.nz/the-press/news/98216065/christchurch-teen-admits-spree-of-violence-at-christchurch-mall.

62 Proctor.

63 'Dannevirke man sentenced for isis propaganda, child sex abuse images', New Zealand Herald, 2018. Available at https://www.nzherald.co.nz/nz/news/article.cfm?c_id=1\&objectid=12037850>.

64 Nightingale.

65 'Teen planned mass shooting at South Island school', Otago Daily Times (Dunedin, New Zealand, 14 November 2020). Available at https://www.odt.co.nz/news/national/teen-planned-mass-shootingsouth-island-school.

66 'NZ youth picked up by the FBI after talking online about carrying out a mass shooting', Stuff. Co.Nz (Wellington, New Zealand, 16 September 2020). Available at https://www.stuff.co.nz/national/ crime/122787244/nz-youth-picked-up-by-fbi-after-talking-online-about-carrying-out-a-mass-shooting.

67 Royal Commission.

68 'Alleged mosque shooter's recent travels outside NZ', RNZ (Wellington, New Zealand, 16 March 2019). Available at https://www.rnz.co.nz/news/chch-terror/384860/alleged-mosque-shooter-s-recenttravels-outside-nz; 'Brenton Tarrant: the "ordinary white man" turned mass murderer', The Telegraph, 2019. Available at https://www.telegraph.co.uk/news/0/brenton-tarrant-ordinary-white-man-turned-massmurderer/.

69 Ward.

70 Reuters, 'Suspected New Zealand attacker donated to Austrian far-right group, officials say', NBC News, 2019. Available at https://www.nbcnews.com/news/world/new-zealand-attacker-linked-austrianfar-right-group-officials-n987846; 'Christchurch mosque shootings: accused gunman donated $\$ 3650$ to far-right French group generation identity', New Zealand Herald, 2019. Available at https://www. nzherald.co.nz/nz/news/article.cfm?c_id=1\&objectid=12219616.

71 Jacinda Ardern, 'National Terrorism Threat Level Moves to Medium', Beehive.Govt.Nz, 2019. Available at https://www.beehive.govt.nz/release/national-terrorism-threat-level-moves-medium.

72 Ministry of Foreign Affairs and Trade, 'International Security', 2017. Available at https://www.mfat. govt.nz/en/peace-rights-and-security/international-security/; Battersby, 'Terrorism Where Terror Is Not: Australian and New Zealand Terrorism Compared'.

73 Combined Threat Assessment Group, "Assessing Terrorism Threats to New Zealand: The Role of the Combined Threat Assessment Group, National Security Journal, (2020). Available at https://doi. org/10.36878/nsj20200202.08; Battersby, 'Terrorism Where Terror Is Not: Australian and New Zealand Terrorism Compared'; Cullen and Reddy.

74 'White supremacists left out of designated terrorists list', Radio New Zealand, 2019. Available at https://www.radionz.co.nz/news/national/386797/white-supremacists-left-out-of-designated-terrorists-list; Kenny; 'Christchurch mosque shootings must end NZ's innocence about right-wing terrorism', Noted.Co.Nz, 2019. Available at https://www.noted.co.nz/currently/christchurch-mosque-shootings-mustend-nzs-innocence-about-right-wing-terrorism/; John Key, 'Review of Foreign Fighters Security Settings to Begin', Beehive.Govt.Nz, 2014. Available at https://www.beehive.govt.nz/release/review-foreign-fighters-security-settings-begin; New Zealand Security Intelligence Service, New Zealand Security Intelligence Service: Annual Report (Wellington, New Zealand, 2018); Cullen and Reddy.

75 “"Skinheads" Pose Potential Security Threat in Wake of Christchurch Terrorist Attack - Paul Buchanan', Tvnz.Co.Nz, 2019. Available at https://www.tvnz.co.nz/one-news/new-zealand/skinheads-pose-potential-security-threat-in-wake-christchurch-terrorist-attack-paul-buchanan.

76 Caitlin Clemmow, Noemie Bouhana, and Paul Gill, 'Analyzing Person-Exposure Patterns in Lone-Actor Terrorism: Implications for Threat Assessment and Intelligence Gathering', Criminology and Public Policy, 19.2 (2020), 451-82.

77 Paul Gill, 'Toward a Scientific Approach to Identifying and Understanding Indicators of Radicalization and Terrorist Intent: Eight Key Problems', Journal of Threat Assessment and Management, 2.3 (2015), 187-91. Available at https://doi.org/10.1037/tam0000047.

78 Schuurman, Bakker, and others; Bouhana, Thornton, and others.

79 In developing TRAP-18, Meloy used the codebook originally developed by Gill in 2015. 
80 Jessica Yakeley and Richard Taylor, 'Terrorism and Mental Disorder, and the Role of Psychiatrists in Counter-Terrorism in the UK', Psychoanalytic Psychotherapy, 31.4 (2017), 378-92. Available at https:// doi.org/10.1080/02668734.2017.1368694.

81 Yakeley and Taylor; Pathé and others; Adam Lankford, 'A Psychological Re-Examination of Mental Health Problems among the 9/11 Terrorists', Studies in Conflict and Terrorism, 41.11 (2017), 875-98. Available at https://doi.org/10.1080/1057610X.2017.1348742; Kamaldeep Bhui and Edgar Jones, 'The Challenge of Radicalisation: A Public Health Approach to Understanding and Intervention', Psychoanalytic Psychotherapy, 31.4 (2017), 401-10. Available at https://doi.org/10.1080/02668734.2017.1354908.

82 Schuurman, Bakker, and others.

83 Hamilton; Mark Hamm and Ramon Spaaj, Lone Wolf Terrorism in America: Using Knowledge of Radicalization Pathways to Forge Prevention Strategies (Indiana, USA, 2015). Available at https://doi. org/10.1016/j.comppsych.2014.05.018.

84 RTI International, 'Countering Violent Extremism: The Use of Assessment Tools for Measuring Violence Risk Literature Review', 2017, 1-40; Loretta Lynch, Karol Mason, and Nancy Rodriguez, Radicalization and Violent Extremism: Lessons Learned from Canada, the U.K. and the U.S. (Arlington, VA, 2015); Hamilton; Gill, Horgan, and Deckert; Meloy and others.

85 Studies incorporated in the table are: Meloy (2016), CLAT project - de Roy van Zuijdewijn and Bakker (2014), Gill, Horgan and Deckert (2014), Spaaj and Haam (2015), Gruenwald (2015), Schuurman, Bakker, Gill and Bouhana (2018), Smith (2018), and the EADR database available at: https://www.start. umd.edu/profiles-individual-radicalization-united-states-pirus-keshif

86 'High' education levels are considered to be anything after high school.

87 Hannah Ritchie and Max Roser, 'Mental Health', Our World in Data, 2018. Available at https://ourworldindata.org/mental-health.

88 Martine Herzog-Evans, 'A Comparison of Two Structured Professional Judgment Tools for Violent Extremism and Their Relevance in the French Context', European Journal of Probation, 10.1 (2018), 3-27. Available at https://doi.org/10.1177/2066220317749140; RTI International, 'Countering Violent Extremism: The Use of Assessment Tools for Measuring Violence Risk Literature Review'

89 This data should be considered preliminary data, as the individuals require further assessment by Police. The percentages provided may be more representative of collection methodologies. New Zealand Police is affected by difficulties with data collection, as is data from most Police jurisdictions internationally - data collection and recording is usually not a true representation of the criminal environment. However, it remains valid to this research because this is what New Zealand national security analysts work with on a daily basis.

90 John Monahan, 'The Individual Risk Assessment of Terrorism: Recent Developments', in The Handbook of the Criminology of Terrorism, ed. by Gary LaFree and Joshua D. Freilich (John Wiley \& Sons, Inc, 2016), pp. 520-34.

91 Dishonesty offending includes offences such as theft, burglary and car theft.

92 Combination of people with a prior offence for violence or an alert for violence.

93 Of the total sample, 41 percent had a prior non-serious violence offence, and $40 \%$ had a prior serious violence offence (prior to their latest offence between 2013-2018). The two percentages cannot be added together. The inference is that the majority are historically violent.

94 People who had either an alert for possess/use firearm, or a prior firearms offence. Offences are not always associated with alerts.

95 Of the total offender group, $8 \%$ had a prior firearms/6800 series charge, as opposed to simply an alert.

96 Also, 2.6\% of violence offenders had previously held a firearms licence which had, at some stage, been revoked.

97 People with a prior offence for sexual offending or an alert for sexual offending.

98 Not diagnosed, but is often coded when Police suspect an individual may have mental health problems.

99 Either as a victim or offender or witness, at some point in their life

100 Gill, Horgan, and Deckert; Meloy and others; Pantucci, Ellis, and Chaplais. 
101 Hamilton; Herzog-Evans; McCauley and Moskalenko, 'Toward a Profile of Lone Wolf Terrorists: What Moves an Individual From Radical Opinion to Radical Action'; Spaaj, Understanding Lone Wolf Terrorism: Global Patterns, Motivations and Prevention.

102 McCauley and Moskalenko, 'Toward a Profile of Lone Wolf Terrorists: What Moves an Individual From Radical Opinion to Radical Action'; John Monahan, 'The Individual Risk Assessment of Terrorism', Psychology, Public Policy and Law, 18.2 (2012), 167-205. Available at https://doi.org/10.1037/ a0025792; Hamilton; Yakeley and Taylor; RTI International, Countering Violent Extremism: The Application of Risk Assessment Tools in the Criminal Justice and Rehabilitation Process (Washington, D.C., 2018); Capellan; John Horgan and others, Across the Universe? A Comparative Analysis of Violent Behavior and Radicalization Across Three Offender Types with Implications for Criminal Justice Training and Education (Washington, D.C., 2016); START, Understanding Lone-Actor Terrorism: A Comparative Analysis with Violent Hate Crimes and Group-Based Terrorism (Washington, D.C., 2013).

103 Horgan and others.

104 J. Reid Meloy and Jessica Yakeley, 'The Violent True Believer as a "Lone Wolf" - Psychoanalytic Perspectives on Terrorism', Behavioral Sciences and the Law, 32.3 (2014). Available at https://doi. org/10.1002/bsl; J. Reid Meloy and Paul Gill, 'The Lone-Actor Terrorist and the TRAP-18', Journal of Threat Assessment and Management, 3.1 (2016), 37-52. Available at https://doi.org/10.1037/ tam0000061; Spaaj, Understanding Lone Wolf Terrorism: Global Patterns, Motivations and Prevention; Adam Lankford, 'Identifying Potential Mass Shooters and Suicide Terrorists With Warning Signs of Suicide, Perceived Victimization, and Desires for Attention or Fame', Journal of Personality Assessment, 100.5 (2018). Available at https://doi.org/10.1080/00223891.2018.1436063; Hamilton; Pantucci, Ellis, and Chaplais.

105 Hamilton.

106 Meloy and Gill.

107 Meloy and Gill; Lankford, 'Identifying Potential Mass Shooters and Suicide Terrorists With Warning Signs of Suicide, Perceived Victimization, and Desires for Attention or Fame'.

108 'Are lone wolf attacks the new normal?', Stuff.Co.Nz, 2016. Available at https://www.stuff.co.nz/ dominion-post/comment/82338042/chris-wilson-are-lone-wolf-attacks-the-new-normal.

109 Andrew Zammit, 'Who Becomes a Jihadist in Australia?', ARC Linkage Project on Radicalisation - Conference 2010: Understanding Terrorism from an Australian Perspective: Radicalisation, De-Radicalisation and Counter Radicalisation, 2011. Available at http://www.arts.monash.edu.au/radicalisation/ conferences-and-events/conference-2011/index.php.

110 'Canadian Soldier Killed by Convert to Islam in Hit and Run', The Guardian, 2014. Available at https:/www.theguardian.com/world/2014/oct/21/canada-soldier-convert-islam-hit-and-run-quebec; Europol, Terrorism Situation and Trend Report 2019; Gill, Horgan, and Deckert; Chris Jasparro, 'Lone Wolf - The Threat from Independent Jihadists', Jane's Intelligence Review, 2010.

111 McCauley and Moskalenko, Friction; Bart Schuurman, Lasse Lindekilde, and others, 'End of the Lone Wolf: The Typology That Should Not Have Been', Studies in Conflict \& Terrorism, 42.8 (2019), 771-78. Available at https://doi.org/10.1080/1057610X.2017.1419554; Hamm and Spaaj, Lone Wolf Terrorism in America: Using Knowledge of Radicalization Pathways to Forge Prevention Strategies; Bouhana, Thornton, and others.

112 Schuurman, Lindekilde, and others; McCauley and Moskalenko, Friction; Spaaj and Winter; Europol, Terrorism Situation and Trend Report 2019; Pantucci, Ellis, and Chaplais; Mark Hamm and Ramon Spaaj, The Age of Lone Wolf Terrorism (New York, NY: Columbia University Press, 2017); Noémie Bouhana, Emily Corner, and others, 'Background and Preparatory Behaviours of Right-Wing Extremist Lone Actors: A Comparative Study', Perspectives on Terrorism, 12.6 (2018), 150-63; Bouhana, Thornton, and others; Europol, Terrorism Situation and Trend Report 2020.

113 Meloy and Gill; Hamilton; Spaaj, Understanding Lone Wolf Terrorism: Global Patterns, Motivations and Prevention; Europol, Terrorism Situation and Trend Report 2020.

114 Meloy and Gill; Hamilton.

115 Spaaj and Winter; Schuurman, Lindekilde, and others.

116 Jeff Gruenewald, Steven Chermak, and Joshua D. Freilich, 'Distinguishing "Loner” Attacks from Other Domestic Extremist Violence: A Comparison of Far-Right Homicide Incident and Offender Characteristics', Criminology and Public Policy, 12.1 (2013), 65-91. Available at https://doi. org/10.1111/1745-9133.12008; Gill, Horgan, and Deckert; Schuurman, Bakker, and others. 
117 Hamm and Spaaj, Lone Wolf Terrorism in America: Using Knowledge of Radicalization Pathways to Forge Prevention Strategies; Michael Jensen and Gary Lafree, Final Report: Empirical Assessment of Domestic Radicalization (EADR) (Washington, D.C., 2016); Spaaj and Winter.

118 Bart Schuurman and Quirine Eijkman, 'Indicators of Terrorist Intent and Capability: Tools for Threat Assessment', Dynamics of Asymmetric Conflict, 8.3 (2015), 215-31. Available at https://doi.org/10.1080/ 17467586.2015.1040426>; Schuurman, Bakker, and others.

119 Allison Smith, Risk Factors and Indicators Associated With Radicalization to Terrorism in the United States: What Research Sponsored by the National Institute of Justice Tells Us (Washington, D.C., 2018); McCauley and Moskalenko, Friction.

120 McCauley and Moskalenko, 'Toward a Profile of Lone Wolf Terrorists: What Moves an Individual From Radical Opinion to Radical Action'; Kate Buggy, Under the Radar: How Might Australia Enhance Its Policies to Prevent 'Lone Wolf' and 'Fixated Person' Violent Attacks? (Canberra, Australia, 2016); Matthijs Nijboer, 'A Review of Lone Wolf Terrorism: The Need for a Different Approach', Social Cosmos, 3.1 (2012); McCauley and Moskalenko, Friction; Hamm and Spaaj, The Age of Lone Wolf Terrorism.

121 Nijboer; Hamm and Spaaj, Lone Wolf Terrorism in America: Using Knowledge of Radicalization Pathways to Forge Prevention Strategies; Hamm and Spaaj, The Age of Lone Wolf Terrorism; Bouhana, Thornton, and others.

122 Lankford, 'Identifying Potential Mass Shooters and Suicide Terrorists With Warning Signs of Suicide, Perceived Victimization, and Desires for Attention or Fame'; Gill, Horgan, and Deckert.

123 McCauley and Moskalenko, Friction.

124 Horgan and others.

125 Hamm and Spaaj, Lone Wolf Terrorism in America: Using Knowledge of Radicalization Pathways to Forge Prevention Strategies.

126 Emily Corner and Paul Gill, 'A False Dichotomy? Mental Illness and Lone-Actor Terrorism', Law and Human Behavior, 39.1 (2015), 23-34. Available at https://doi.org/10.1037/lhb0000102; Spaaj, Understanding Lone Wolf Terrorism: Global Patterns, Motivations and Prevention; de Roy van Zuijdewijn and Bakker; Gill, Horgan, and Deckert.

127 Meloy and Gill; Bakker and de Roy van Zuijdewijn; Corner and Gill, 'Mental Health and Terrorism'; Hamm and Spaaj, The Age of Lone Wolf Terrorism; Schuurman and Eijkman; Jensen and Lafree; Australian Strategic Policy Institute.

128 Delusional disorder is a type of schizophrenia.

129 Emily Corner and others, 'Mental Health Disorders and the Terrorist: A Research Note Probing Selection Effects and Disorder Prevalence', Studies in Conflict \& Terrorism, 39.6 (2016), 560-68. Available at https://doi.org/10.1080/1057610X.2015.1120099; D. V. James and others, 'The Role of Mental Disorder in Attacks on European Politicians 1990-2004', Acta Psychiatrica Scandinavica, 116.5 (2007), 334-44. Available at https://doi.org/10.1111/j.1600-0447.2007.01077.x; Anton Weenink, 'Behavioral Problems and Disorders among Radicals in Police Files', Perspectives on Terrorism, 9.2 (2015), 17-33. 130 Corner and Gill, 'A False Dichotomy? Mental Illness and Lone-Actor Terrorism'.

131 Mental Health Foundation, 'Mental Health Foundation: Quick Facts and Stats 2014', 2014. Available at https://www.mentalhealth.org.nz/assets/Uploads/MHF-Quick-facts-and-stats-FINAL-2016.pdf. 132 Meloy and others; Behavioral Analysis Unit - Federal Bureau of Investigation, Making Prevention a Reality: Identifying, Assessing, and Managing the Threat of Targeted Attacks (Quantico, VA, 2017); Jensen and Lafree.

133 Elizabeth Walsh, Alec Buchanan, and Thomas Fahy, 'Violence and Schizophrenia: Examining the Evidence', British Journal of Psychiatry, 180.6 (2002).

134 Corner and Gill, 'A False Dichotomy? Mental Illness and Lone-Actor Terrorism'.

135 Corner and Gill, ‘A False Dichotomy? Mental Illness and Lone-Actor Terrorism'; Corner and others; Spaaj, Understanding Lone Wolf Terrorism: Global Patterns, Motivations and Prevention; Sam Mullins, 'The Road to Orlando: Jihadist-Inspired Violence in the West, 2012-2016', CTC Sentinel, 2016; Pathé and others; de Roy van Zuijdewijn and Bakker; Gill, Horgan, and Deckert; Yakeley and Taylor; Martin Gallagher, 'The 2016 'Lone Wolf” Tsunami - Is Rapoport's “Religious Wave” Ending?', 10.2 (2017), 60-76. Available at https://doi.org/10.5038/1944-0472.10.2.1584; J. Reid Meloy and Jacqueline Genzman, 'The Clinical Threat Assessment of the Lone-Actor Terrorist', Psychiatric Clinics of North America, 39.4 (2016), 649-62. Available at https://doi.org/10.1016/j.psc.2016.07.004. 
136 Behavioral Analysis Unit - Federal Bureau of Investigation.

137 Gill, Horgan, and Deckert; Horgan and others.

138 Office of Intelligence and Analysis, Rightwing Extremism: Current Economic and Political Climate Fueling Resurgence in Radicalization and Recruitment (Washington, D.C., 2009); Hamm and Spaaj, Lone Wolf Terrorism in America: Using Knowledge of Radicalization Pathways to Forge Prevention Strategies; Jensen and Lafree.

139 Office of Intelligence and Analysis.

140 Office of Intelligence and Analysis.

141 Hamm and Spaaj, The Age of Lone Wolf Terrorism.

142 Andrew Bridgman, 'Criminal Justice Stats and Facts', New Zealand Law Society, 2018. Available at https://www.lawsociety.org.nz/practice-resources/practice-areas/criminal-law/criminal-justice-stats-andfacts.

143 Horgan and others.

144 Hamm and Spaaj, Lone Wolf Terrorism in America: Using Knowledge of Radicalization Pathways to Forge Prevention Strategies; Smith; J. Reid Meloy, 'The Operational Development and Empirical Testing of the Terrorist Radicalization Assessment Protocol (TRAP-18)', Journal of Personality Assessment, 100.5 (2018), 483-92. Available at https://doi.org/10.1080/00223891.2018.1481077; Horgan and others; Pantucci, Ellis, and Chaplais.

145 Meloy.

146 Smith and others.

147 Hamm and Spaaj, The Age of Lone Wolf Terrorism.

148 Nightingale.

149 Clare Ellis and others, Lone-Actor Terrorism Analysis Paper (London, England, 2016).

150 Gill, Horgan, and Deckert.

151 Spaaj and Winter; Gill, Horgan, and Deckert.

152 Spaaj and Winter.

153 Europol, Terrorism Situation and Trend Report 2020.

154 Spaaj and Winter; Bouhana, Corner, and others.

155 Clare Ellis and Raffaello Pantucci, 'Leakage' and Interaction with Authorities (London, England, 2016).

156 Schuurman, Bakker, and others.

157 Behavioral Analysis Unit - Federal Bureau of Investigation.

158 Ellis and Pantucci; Bouhana, Thornton, and others.

159 Monica Lloyd and Christopher Dean, 'The Development of Structured Guidelines for Assessing Risk in Extremist Offenders.', Journal of Threat Assessment and Management, 2.1 (2015), 40-52. Available at https://doi.org/10.1037/tam0000035.

160 Herzog-Evans.

161 Spaaj, Understanding Lone Wolf Terrorism: Global Patterns, Motivations and Prevention; Lloyd and Dean; Michael Becker, 'Explaining Lone Wolf Target Selection in the United States', Studies in Conflict \& Terrorism, 37 (2014), 959-78. Available at https://doi.org/10.1080/1057610X.2014.952261.

162 Europol, Terrorism Situation and Trend Report 2019.

163 Spaaj, Understanding Lone Wolf Terrorism: Global Patterns, Motivations and Prevention; DHS Intelligence Enterprise.

164 'Canadian soldier killed by convert to Islam in hit and run', The Guardian, 2014. Available at https:// www.theguardian.com/world/2014/oct/21/canada-soldier-convert-islam-hit-and-run-quebec.

165 'Darren Osborne jailed for life for Finsbury Park terrorist attack', The Guardian, 2018. Available at https://www.theguardian.com/uk-news/2018/feb/02/finsbury-park-attack-darren-osborne-jailed.

166 Spaaj, Understanding Lone Wolf Terrorism: Global Patterns, Motivations and Prevention.

167 Bouhana, Thornton, and others.

168 Spaaj, Understanding Lone Wolf Terrorism: Global Patterns, Motivations and Prevention; Schuurman, Bakker, and others; Hamilton. 
169 Schuurman, Bakker, and others.

170 Lloyd and Dean; Bouhana, Thornton, and others.

171 McCauley and Moskalenko, Friction.

172 Bouhana, Thornton, and others; Schuurman, Bakker, and others.

173 Schuurman and Eijkman; Schuurman, Bakker, and others; Lloyd and Dean; Horgan and others;

Spaaj, Understanding Lone Wolf Terrorism: Global Patterns, Motivations and Prevention; Bouhana,

Thornton, and others; Hamilton; Behavioral Analysis Unit - Federal Bureau of Investigation.

174 Bouhana, Thornton, and others.

175 Hamilton; Gill; Randy Borum, 'Operationally Relevant Research and Practice in Terrorism Threat Assessments', Journal of Threat Assessment and Management, 2.3-4 (2015), 192-94; RTI International, 'Countering Violent Extremism: The Use of Assessment Tools for Measuring Violence Risk Literature Review'.

176 Gill; Meloy and Gill.

177 Hamilton; Gill.

178 Stijn Sieckelinck and Amy-Jane Gielden, Protective and Promotive Factors Building Resilience against Violent Radicalisation, 2018.

179 RTI International, Countering Violent Extremism: The Application of Risk Assessment Tools in the Criminal Justice and Rehabilitation Process; Herzog-Evans.

180 Smith.

181 National Institute of Justice, 'Research and Evaluation on Domestic Terrorism Prevention' (Washington, D.C., 2019).

182 Hamilton; Gill; RTI International, 'Countering Violent Extremism: The Use of Assessment Tools for Measuring Violence Risk Literature Review'; Behavioral Analysis Unit - Federal Bureau of Investigation; Smith.

183 Hamilton.

184 Gill.

185 Geoff Dean and Graeme Pettet, 'The 3 R's of Risk Assessment for Violent Extremism', Journal of Forensic Practice, 19.2 (2017), 91-101. Available at https://doi.org/10.1108/JFP-07-2016-0029. 